\title{
Me and the Mosque
}

Zarqa Nawaz, author and director

National Film Board of Canada, 2005. 52 minutes.

Zarqa Nawaz is a Canadian Muslim filmmaker who lives with her family in Regina, Saskatchewan. There are any number of comments that could be inserted at this point. Having spent time on both the Saskatchewan and Manitoba prairies, I note only that Zarqa is developing a television series for the Canadian Broadcasting Corporation entitled "Little Mosque on the Prairie." She has made two earlier short films, BBQ Muslims and Death Threat. Information about those films, as well as about Zarqa, can be found on her website, Fundamentalist Films, available at www.fundamentalistfilms.com.

Me and the Mosque, her first documentary, is distributed by the National Film Board of Canada. The film is directly related to her own concerns as a Muslim woman, namely, as to space available to her in the mosque. The film begins on a light-hearted note (as does her web site, with the tag line of "putting the fun back into fundamentalism") with Muslim comic Azhar Usman joking about the lack of appropriate space available in mosques for Muslim women.

The documentary traverses mosques in Canada and the United States, such including places as Aurora, Illinois; Mississauga, Ontario; Winnipeg, Manitoba; Regina, Saskatchewan; Surrey, British Columbia; and Morgantown, West Virginia. It includes the voices of established scholars, among them Asma Barlas, Umar Abd-Allah, and Aminah McCloud, alongside the newer scholarly voices of Aisha Geissinger, Jasmine Zine, and Itrath Syed. In addition, there is a wide range of interviews with people from the Muslim community, from such activists as Asra Nomani and Aminah Assilmi to such scholars as Abdullah Adhami and Tareq Suwaidan.

As mentioned above, the film begins on a humorous note with the comedy of Azhar Usman (of "Allah Made Me Funny" fame). However, what he jokes about, the nice "dungeons" that many people mention when they talk about the basements where some mosques give space to women, is no laughing matter. The film then moves to the mosque in Aurora to begin its discussion of these issues. I would like to think that this is Zarqa's subtle homage to another Canadian filmmaker, Mike Myers, who bases his fictional character, Wayne Campbell, in Aurora. Zarqa then mentions her upbringing in Toronto and contrasts the mosque that she attended (the Jami' Mosque) while 
growing up with the mosque currently attended by her mother, the new Islamic Centre of Canada in Mississauga (the Canadian headquarters of the Islamic Society of North America). Her discussions with her mother raise questions about differences based in generations and experiences in countries of origin. In Pakistan, for example, mosque space may be exclusively male space, but in Canada the mosque may be the only Muslim space available to women. As such, women in Pakistan and Canada may have very different attitudes about the space available to them in mosques.

In addition to the number of mosques visited in the United States, Zarqa includes footage of a recent ISNA conference in Chicago. At that conference, she was able to interview a number of African-American Muslims about their views on women in the mosque. This is one of the most important segments in the video, as African-American Muslims have had a much longer history than immigrant Muslims of trying to balance what it means to be "American" (or "Canadian," for that matter) with what it means to be "Muslim." The film also mentions converts to Islam, including one young woman who converted because she found Islam to be a religion that honors women, only to have that impression change when her local mosque erected a physical barrier between men and women.

The film is a gem. It is recommended, perhaps even required viewing, for both Muslims and those interested in Islam. The film can also be used with great success in courses about Islam or women in religion. My own students appreciated the humor (the cartoon segments are a particular favorite) used to illustrate situations that are often not very funny. Muslim women in North America are dealing with very serious issues around their participation in religious life at the mosque, and this film captures those issues with eloquence and poise. 